\title{
Monophasic synovial sarcoma presenting as a primary ileal mass: a case report and review of the literature
}

\author{
Alaa N Alsharief, Musa Fageeh and Yousof Alabdulkarim*
}

\begin{abstract}
Introduction: Synovial sarcoma is a rare malignant mesenchymal tumor mainly arising in the peri-articular tissue in young adults. There are few cases reported in other areas.

Case presentation: We report the case of a 29-year-old Saudi woman of Arabian ethnicity with synovial sarcoma arising primarily from the ileum who presented with abdominal pain, a palpable mass and incomplete intestinal obstruction. A literature review was performed to gather information on this rare gastrointestinal tract sarcoma.

Conclusions: Although it is a rare tumor of the pre-articular tissues, synovial sarcoma can present, in exceedingly rare cases, in unusual anatomical sites such as the gastrointestinal tract. We believe the reporting of all rare or unexpected presentations of sarcoma will eventually improve our understanding of this relatively unusual malignancy.
\end{abstract}

\section{Introduction}

Synovial sarcoma is a malignant mesenchymal tumor of uncertain histogenesis. It may be biphasic, monophasic, or poorly differentiated [1]. Synovial sarcoma is a rare entity representing $5 \%$ to $10 \%$ of all soft tissue sarcomas, typically occurring around the joints, mainly the knee $[2,3]$. Occasionally, it arises in the head and neck $[4,5]$, lungs [6-8], heart [9], retroperitoneum [10], prostate [11] and intra-neurally [12]. There are few cases reported of synovial sarcoma arising in the gastrointestinal tract. We report the case of primary synovial sarcoma arising in the ileum of a 29 -year-old woman. Our patient's tumor displayed morphologic features and immunohistochemical staining consistent with this disease. We believe that our case is the first reported case of monophasic synovial sarcoma arising from the ileum.

\section{Case presentation}

A 29-year-old Saudi woman presented to our Emergency Room with a five-day history of epigastric and lower abdominal pain associated with lower abdominal and pelvic fullness that she attributed to fibroids. The

\footnotetext{
* Correspondence: Yalabdulkarim@gmail.com
King Fahad Medical City, Riyadh, Saudi Arabia, P.O. Box 59046, Riyadh 11525

* Correspondence: Yalabdulkarim@gmail.com
King Fahad Medical City, Riyadh, Saudi Arabia, P.O. Box 59046, Riyadh 11525 Kingdom of Saudi Arabia
}

(C) 2012 Alsharief et al; licensee BioMed Central Ltd. This is an Open Access article distributed under the terms of the Creative Commons Attribution License (http://creativecommons.org/licenses/by/2.0), which permits unrestricted use, distribution, and reproduction in any medium, provided the original work is properly cited.

pain was intermittent, colicky in nature and associated with nausea and vomiting. She denied any history of fever and there had been no change in her bowel habits or urinary symptoms. For several months she had been followed up regularly at the gynecology clinic due to the lower abdominal heaviness and distension. Her gynecological history revealed a nulliparous woman with no vaginal bleeding. Her medical history was significant for epilepsy since childhood, which was well controlled by medication, and a laparoscopic appendectomy one year ago. On examination, she was alert and conscious. Her vital signs were stable. Her abdomen was distended with a palpable pelvic-abdominal mass that was hard, nontender and slightly mobile. Her liver and spleen were within the normal range and she had normal bowel sounds. No lymph nodes were enlarged and digital rectal examination revealed no abnormalities.

A computed tomography (CT) scan of her abdomen and pelvis showed a pelvic/abdominal mass adjacent to the distal small bowel loops separate from the uterus and ovaries, heterogeneously enhancing, measuring roughly $65 \times 99 \mathrm{~mm}$ with multiple areas of necrosis (Figure 1A, B). A CT scan of her chest showed indeterminate multiple bilateral subpleural $2 \mathrm{~mm}$ to $4 \mathrm{~mm}$ lung nodules, too small to biopsy. 


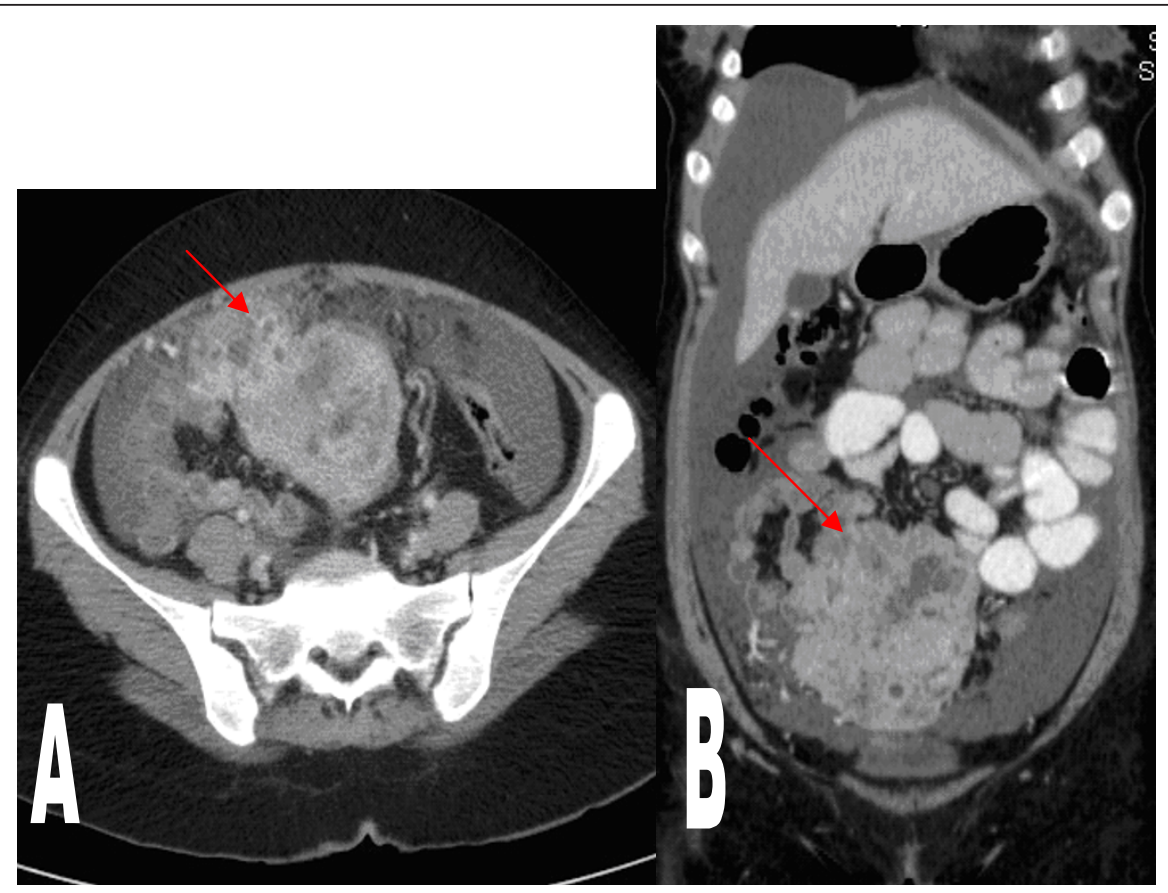

Figure 1 (A, B) Computed tomography (CT) axial and coronal cuts showing the pelvic/abdominal heterogeneous mass with areas of necrosis in addition to ascites.

The case was discussed by the multidisciplinary tumor board and the advice was to confirm the diagnosis to eliminate the possibility of an ovarian origin of the tumor because of its very close proximity.

Surgical exploration was indicated due to the finding of a large mass that was composed of a cystic and also a large solid component that needed to be investigated to eliminate the possibility of lymphoma or tuberculosis, which is quite common in our population. However, there was some radiological confusion about the origin of this mass and to some colleagues it was necessary to confirm it with a histological biopsy. For this reason, our patient underwent diagnostic laparoscopy, which showed a moderate amount of ascetic fluid with a large mass in the lower abdomen. When a biopsy was attempted, a large vein on the mass ruptured and bleeding made visualization extremely difficult. Therefore, the procedure was converted to an open one through a small lower midline incision. A $10 \times 10 \mathrm{~cm}$ mass arising from the terminal ileum, occupying the pelvis and reaching to the umbilical area was found.

The uterus, ovaries and the urinary bladder were not involved. After a minimal dissection the tumor was excised with $10 \mathrm{~cm}$ free margins of small bowel and primary side-to-side anastomosis was performed. Our patient tolerated the procedure very well and her recovery period was unremarkable. She was discharged home on the seventh post-operative day. She was reviewed on an out-patient basis by our colleagues in radio-oncology and due to the radical nature of the surgery she was not offered any adjuvant treatment. She is still being followed up by our surgical oncology team and has shown no evidence of local or distant metastasis based on clinical and CT scan results after 24 months of follow-up.

Gross pathology revealed a segment of small bowel measuring $17 \times 2 \mathrm{~cm}$. It was adherent to a portion of ascending colon. An $8 \times 7 \times 3 \mathrm{~cm}$ white solid mass with a homogeneous cut surface was bulging from the serosal side of the small bowel; it was $4 \mathrm{~cm}$ away from the proximal resection margin. The tumor was adherent to the large bowel but not infiltrating it grossly. Few lymph nodes were identified within the mesenteric fat. Microscopy showed that the tumor was composed of cellular spindle cells with a mild to moderate degree of pleomorphism arising from the small bowel wall and mainly involving the submucosa, muscularis propria and serosa. Focal mucosal erosion was identified. The tumor cells showed a moderate amount of eosinophilic cytoplasm, evenly distributed nuclear chromatin and a few conspicuous nuclei (Figure 2A, B). The mitotic count was one to two per 10 high-power fields. A metastatic focus was identified within a single mesenteric lymph node (Figure 2C).

Immunohistochemical testing results showed that the tumor was positive for S100, epithelial membrane antigen (EMA), B cell lymphoma 2 ( $\mathrm{Bcl} 2)$, and vimentin (Figure 3A-C). CD99 tests were negative (Figure 3F) and 

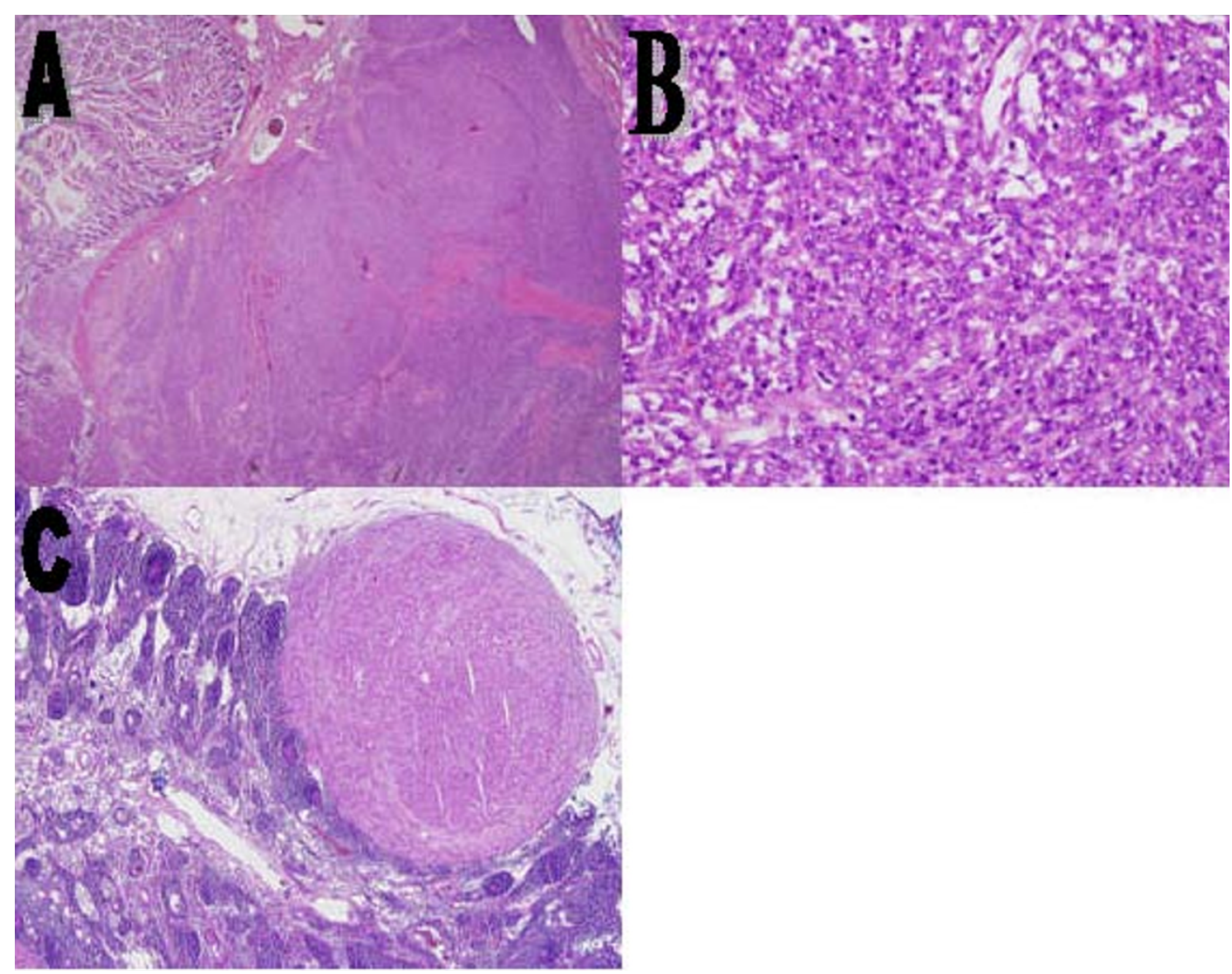

Figure 2 (A) A spindle cell neoplasm arising from the wall of the small bowel and pushing the mucosa toward the lumen, (B) spindle cells with mild to moderate degree of pleomorphism and few conspicuous nuclei, and (C) a spindle cell metastatic focus in a mesenteric lymph node (hematoxylin and eosin; (A) $\times 2$, (B) $\times 20$, (C) $\times 4$ ).

CDl17 tests were positive (Figure 3E), in addition to calretinin (focal) and synaptophysin (focal), and CD56 (few cells). The specimen tested negative for CD34, CAM5.2, cytokeratin 7, 20, and 5/6 (Figure 3H), cytokeratin AE1/ AE3, neuron-specific enolase (NSE), CD31, desmin (Figure $3 G$ ), chromogranin, smooth muscle actin (SMA), HMB45, factor 8, Ber/EB4, and melan-A.

A cytogenetic study of the specimen was conducted on a formalin fixed paraffin embedded tumor sample. The result of a real-time polymerase chain reaction (RT-PCR) procedure for synovial sarcoma-associated fusion transcript (SYT-SSX1 and SYT-SSX2) was negative.

Our patient was seen periodically in our surgical oncology clinic and she has remained disease free for 24 months with no clinical or radiological evidence of local recurrence.

\section{Discussion}

Gastrointestinal sarcoma accounts for $0.1 \%$ to $3 \%$ of all gastrointestinal (GI) malignancies and approximately $10 \%$ of all sarcomas $[13,14]$. In the ileum, the majority of malignant sarcomas are GI stromal tumors (GISTs) [15]. To the best of our knowledge there have been only 27 reported cases of synovial sarcoma arising in the GI tract, and none of them in the ileum [16-32]. All of them shared the diagnostic histology and immunohistochemical features of synovial sarcoma. In $64 \%$ of the cases, the characteristic $(\mathrm{X} ; 18)$ translocation was identified. We made the diagnosis in our patient's case based on the histology of monophasic synovial sarcoma and the Immunohistochemical features. Although the molecular assay results were negative for SYT-SSX1 and SYT-SSX2, the combined histological and Immunohistochemical profiles were highly characteristic of monophasic synovial sarcoma.

The median age at diagnosis was 41.5 years (range, 14 to 75 years). There is no significant sex predilection with a male to female ratio of 1:1.15. There are 11 and 12 cases of GI tract synovial sarcoma arising from the esophagus (including one from the gastroesophageal junction) and stomach, respectively, representing the most common sites. The presenting symptoms were 


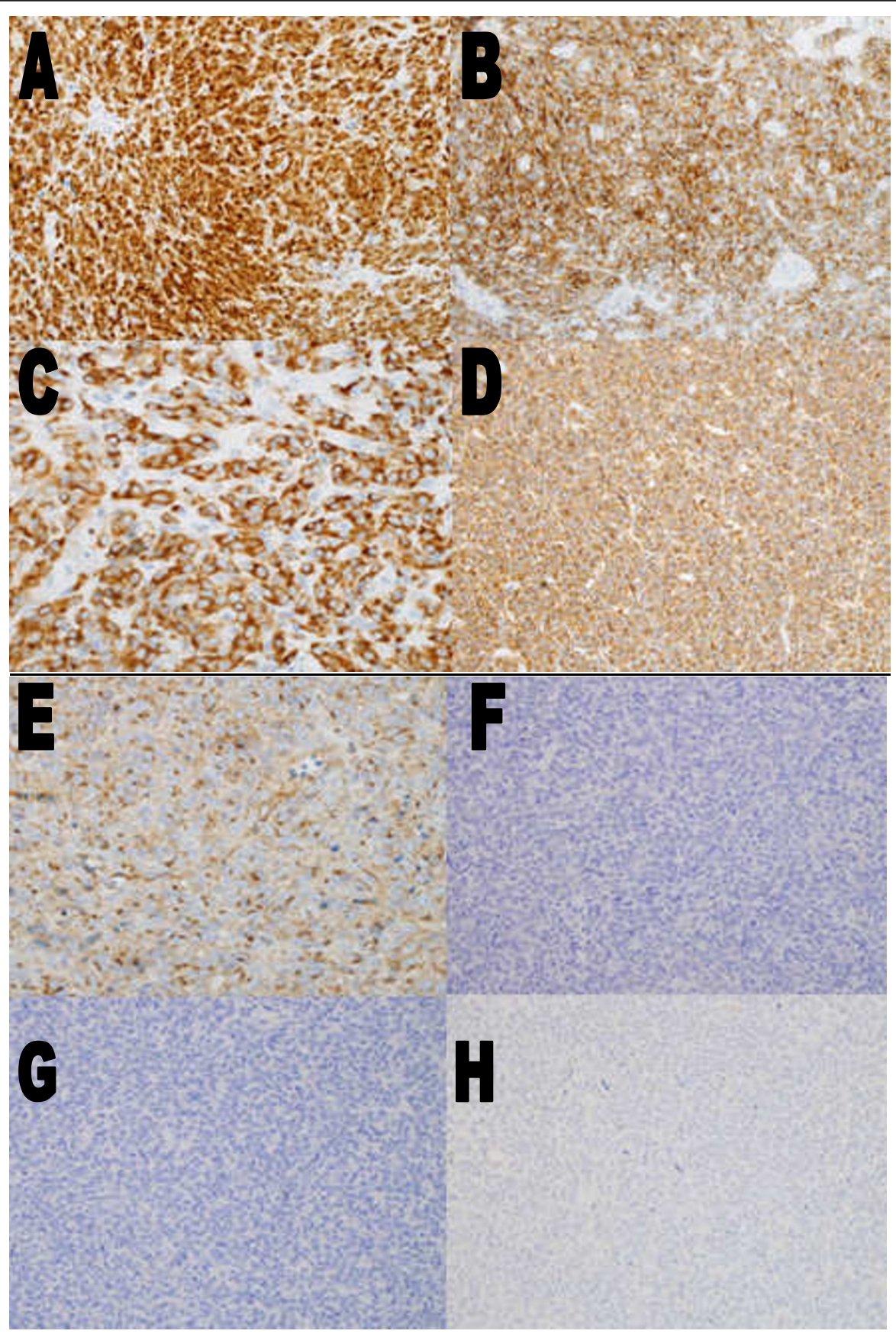

Figure 3 Immunohistochemical staining. (A) S100, $\times 20$; (B) epithelial membrane antigen (EMA), $\times 20$; (C) B cell lymphoma 2 (BCl 2), $\times 40 ;($ D) vimentin, $\times 20$; (E) CD117, ×20; (F) CD99, ×20; (G) desmin, ×20; (H) cytokeratin (CK)5/6, ×20.

pain, obstruction or bleeding. The histological subtypes were monophasic in 15 patients and biphasic in 11 patients including two patients with a poorly differentiated component. The remaining patients' histological subtypes have not been reported. All of the reported cases were treated surgically. The number of patients who received adjuvant chemotherapy or radiotherapy or both are five, four and three, respectively. Only one patient had metastasis at first presentation. Billings [25] reported a patient with gastric synovial sarcoma with multiple liver metastases who died of the disease after six months. The survival period after diagnosis of all reported cases ranged from 1 to 224 months (Table 1).

In soft tissue synovial sarcoma, numerous studies over the years have reported that it is a high grade malignancy with a high rate of metastasis leading to death; 
Table 1 Summary of the reported cases of primary synovial sarcoma in the gastrointestinal tract

\begin{tabular}{|c|c|c|c|c|c|c|c|c|c|c|}
\hline $\begin{array}{l}\text { Author, year, } \\
\text { reference }\end{array}$ & Location & $\begin{array}{l}\text { Presenting } \\
\text { symptoms }\end{array}$ & $\begin{array}{l}\text { Age, } \\
\text { years }\end{array}$ & Gender & $\begin{array}{l}\text { Size, } \\
\mathrm{cm}\end{array}$ & $\begin{array}{l}\text { Gross } \\
\text { features }\end{array}$ & $\begin{array}{l}\text { Histologic } \\
\text { type }\end{array}$ & Translocation & Treatment & $\begin{array}{l}\text { Status and } \\
\text { follow-up, } \\
\text { months }\end{array}$ \\
\hline $\begin{array}{l}\text { Palmer et al. } \\
1983 \text { [16] }\end{array}$ & Esophagus & Dysphagia & 75 & $\mathrm{~F}$ & 2.5 & Polypoid & Biphasic & - & S+Rad & DOD, 24 \\
\hline $\begin{array}{l}\text { Amr et al. } 1984 \\
\text { [17] }\end{array}$ & Esophagus & Dysphagia & 25 & M & 5 & Polypoid & Biphasic & - & S+Rad & AWOD, 36 \\
\hline $\begin{array}{l}\text { Bloch et al., } \\
1987 \text { [18] }\end{array}$ & Esophagus & $\begin{array}{l}\text { Dysphagia, } \\
\text { dyspnea }\end{array}$ & 15 & M & 7 & Polypoid & Biphasic & - & S+Rad & AWOD, 36 \\
\hline $\begin{array}{l}\text { Pulpiero et al., } \\
1988 \text { [19] }\end{array}$ & Esophagus & & 24 & M & & & Biphasic & - & $S$ & NR \\
\hline $\begin{array}{l}\text { Caldwell et al., } \\
1991 \text { [20] }\end{array}$ & Esophagus & & 29 & $\mathrm{~F}$ & & & NR & - & $\begin{array}{l}\text { S+Rad } \\
\text { +Chemo }\end{array}$ & AWOD, 195 \\
\hline $\begin{array}{l}\text { Perch et al., } \\
1991 \text { [21] }\end{array}$ & Esophagus & & 15 & M & & & Biphasic & - & S+Rad & $\begin{array}{l}\text { AWOD, } 5 \text { to } 6 \\
\text { years after } \\
\text { surgery }\end{array}$ \\
\hline $\begin{array}{l}\text { Antón-Pacheco } \\
\text { et al., } 1996 \text { [22] }\end{array}$ & Esophagus & $\begin{array}{l}\text { Dysphagia, } \\
\text { weight loss }\end{array}$ & 14 & $\mathrm{~F}$ & 7 & Polypoid & Biphasic & - & $\begin{array}{l}\text { S+Chemo } \\
\text { +Rad }\end{array}$ & AWOD, 30 \\
\hline $\begin{array}{l}\text { Habu S et al. } \\
1998[23]\end{array}$ & Esophagus & $\begin{array}{l}\text { Sensation of } \\
\text { something } \\
\text { stuck in the } \\
\text { throat }\end{array}$ & 20 & M & 8 & Polypoid & Biphasic & - & $\begin{array}{l}\text { S+Chemo } \\
\text { +Rad }\end{array}$ & AWOD, 20 \\
\hline $\begin{array}{l}\text { Bonavina et al., } \\
1998 \text { [24] }\end{array}$ & Esophagus & Achalasia & 63 & $\mathrm{~F}$ & & Polypoid & NR & - & - & - \\
\hline $\begin{array}{l}\text { Billings et al., } \\
2000 \text { [25] }\end{array}$ & $\begin{array}{l}\text { Gastroesophageal } \\
\text { junction }\end{array}$ & $\begin{array}{l}\text { Incidental } \\
\text { finding for } \\
\text { pyloric } \\
\text { stenosis }\end{array}$ & 47 & M & 5.2 & Polypoid & Biphasic & $t(X ; 18)$ & S & AWOD, 21 \\
\hline $\begin{array}{l}\text { Billings et al., } \\
2000 \text { [25] }\end{array}$ & Stomach & $\begin{array}{l}\text { Abdominal } \\
\text { pain, } \\
\text { nausea, } \\
\text { vomiting } \\
\text { and rectal } \\
\text { bleeding }\end{array}$ & 55 & $\mathrm{~F}$ & 16 & $\begin{array}{l}\text { Spherical, } \\
\text { intramural }\end{array}$ & $\begin{array}{l}\text { Biphasic and } \\
\text { PDSS }\end{array}$ & $t(X ; 18)$ & S & DOD, 6 \\
\hline $\begin{array}{l}\text { Chan et al., } 2004 \\
\text { [26] }\end{array}$ & Jejunum & $\begin{array}{l}\text { Epigastric } \\
\text { pain, } \\
\text { vomiting } \\
\text { and fever }\end{array}$ & 28 & M & 15 & $\begin{array}{l}\text { Polypoid, } \\
\text { intramural }\end{array}$ & Monophasic & $t\left(X_{;} ; 18\right)$, SSX2 & S & DOD, 1 \\
\hline $\begin{array}{l}\text { Butori et al., } \\
2006 \text { [27] }\end{array}$ & Esophagus & Dysphagia & 72 & $\mathrm{~F}$ & 11 & Polypoid & Biphasic & $t(X ; 18)$ & S+Chemo & 6 \\
\hline $\begin{array}{l}\text { Akhunji et al., } \\
2007 \text { [28] }\end{array}$ & Stomach & $\begin{array}{l}\text { Epigastric } \\
\text { pain }\end{array}$ & 42 & M & 11 & & Biphasic & $t(X ; 18)$ & S+Chemo & DOD, 24 \\
\hline $\begin{array}{l}\text { Parfitt et al., } \\
2007 \text { [29] }\end{array}$ & Colon & $\begin{array}{l}\text { Rectal } \\
\text { bleeding }\end{array}$ & 32 & M & 2 & Polypoid & Monophasic & $t(X ; 18)$ & S & 5 \\
\hline $\begin{array}{l}\text { Schreiber- } \\
\text { Fracklam et al., } \\
2007 \text { [30] }\end{array}$ & Distal duodenum & $\begin{array}{l}\text { Abdominal } \\
\text { pain }\end{array}$ & 39 & F & 5 & Polypoid & Monophasic & $\mathrm{t}(\mathrm{X} ; 18), \mathrm{SSX} 2$ & S+Chemo & $\begin{array}{l}\text { Recurrence } 8 \\
\text { months after } \\
\text { surgery }\end{array}$ \\
\hline $\begin{array}{l}\text { Makhlouf et al., } \\
2008 \text { [32] }\end{array}$ & Stomach & & 67 & $\mathrm{~F}$ & 0.8 & & Monophasic & $t(X ; 18)$ & S & AWOD, 12 \\
\hline $\begin{array}{l}\text { Makhlouf et al., } \\
2008 \text { [32] }\end{array}$ & Stomach & & 49 & M & 2 & & $\begin{array}{l}\text { Monophasic } \\
\text { with a poorly } \\
\text { differentiated } \\
\text { component }\end{array}$ & $\mathrm{t}(\mathrm{X} ; 18)$ & S & $\begin{array}{l}\text { DOD, omental } \\
\text { metastasis, } 29\end{array}$ \\
\hline $\begin{array}{l}\text { Makhlouf et al., } \\
2008 \text { [32] }\end{array}$ & Stomach & & 68 & F & 2 & & Monophasic & $t(X ; 18)$ & S & AWOD, 22 \\
\hline $\begin{array}{l}\text { Makhlouf et al., } \\
2008 \text { [32] }\end{array}$ & Stomach & & 29 & M & 2.8 & & Monophasic & $\mathrm{t}(\mathrm{X} ; 18)$ & S & AWOD, 224 \\
\hline $\begin{array}{l}\text { Makhlouf et al., } \\
2008 \text { [32] }\end{array}$ & $\begin{array}{l}\text { Stomach, } \\
\text { gastrodudenal } \\
\text { junction }\end{array}$ & & 54 & $\mathrm{~F}$ & 3 & & Monophasic & $t(X ; 18)$ & S & Recent case \\
\hline Makhlouf et al., & Stomach & & 58 & $\mathrm{~F}$ & 3 & & Monophasic & $t(X ; 18)$ & S & AWOD, 21 \\
\hline
\end{tabular}


Table 1 Summary of the reported cases of primary synovial sarcoma in the gastrointestinal tract (Continued)

\begin{tabular}{|c|c|c|c|c|c|c|c|c|c|c|}
\hline $\begin{array}{l}\text { Makhlouf et al., } \\
2008 \text { [32] }\end{array}$ & Stomach & & 37 & $\mathrm{~F}$ & 4 & & Monophasic & $t(X ; 18)$ & $S$ & $\begin{array}{l}\text { Local } \\
\text { recurrence, re- } \\
\text { excised. DOC } \\
48\end{array}$ \\
\hline $\begin{array}{l}\text { Makhlouf et al., } \\
2008 \text { [32] }\end{array}$ & Stomach & & 50 & M & 6 & & Monophasic & $t(X ; 18)$ & S+Chemo & $\begin{array}{l}\text { Alive with } \\
\text { recurrence, } 6\end{array}$ \\
\hline $\begin{array}{l}\text { Makhlouf et al., } \\
2008 \text { [32] }\end{array}$ & Stomach & & 42 & M & 8 & Polypoid & Biphasic & $\mathrm{t}(\mathrm{X} ; 18)$ & S+Chemo & DOD, 25 \\
\hline $\begin{array}{l}\text { Makhlouf et al., } \\
2008 \text { [32] }\end{array}$ & Stomach & & 66 & $\mathrm{~F}$ & 15 & Polypoid & Monophasic & $t(X ; 18)$ & $S$ & $\begin{array}{l}\text { Lost to follow- } \\
\text { up }\end{array}$ \\
\hline $\begin{array}{l}\text { Company et al., } \\
2009 \text { [31] }\end{array}$ & $\begin{array}{l}\text { Proximal } \\
\text { duodenum }\end{array}$ & $\begin{array}{l}\text { Weight loss } \\
\text { asthenia } \\
\text { anorexia, } \\
\text { nausea, } \\
\text { epigastric } \\
\text { pain }\end{array}$ & 69 & $\mathrm{~F}$ & 8 & $\begin{array}{l}\text { Spherical, } \\
\text { intramural }\end{array}$ & Monophasic & $t(X ; 18)$ & $S$ & $\begin{array}{l}\text { Died due to } \\
\text { complications, } \\
1\end{array}$ \\
\hline $\begin{array}{l}\text { Present case, } \\
2010\end{array}$ & Ileum & $\begin{array}{l}\text { Abdominal } \\
\text { pain, } \\
\text { distension } \\
\text { and } \\
\text { heaviness }\end{array}$ & 39 & $\mathrm{~F}$ & 8 & Intramural & Monophasic & - & $S$ & AWOD, 6 \\
\hline
\end{tabular}

The second case reported by Billings [25] could represent a metastatic focus of a primary neck tumor as it showed the same histopathological features. AWOD = alive without evidence of disease; $A W D=$ alive with residual disease; Chemo = chemotherapy; DOC = died of other cause; $D O D=$ died of disease; $\mathrm{NR}=$ not reported; Rad = radiotherapy; S = surgery; SSX = synovial sarcoma-associated fusion transc; PDSS = Poorly difrentiated synovial sarcoma

10 -year survival rates between $24 \%$ to $68 \%$ and $11 \%$ to $56 \%$ have been reported $[27,33]$.

In the article by Bergh et al. [33], the investigators divided patients with synovial sarcoma into low-risk and high-risk groups depending on their age, tumor size and grade as follows: low-risk group (patient age $<25$ years, tumor size $<5 \mathrm{~cm}$, and no histologic evidence of poorly differentiated tumor); high-risk group (patient age approximately 25 years, tumor size approximately $5 \mathrm{~cm}$, and poorly differentiated tumor). The question is, can we apply the same risk factors to patients with GI synovial sarcoma? To answer such a question we need to diagnose more cases and collect more data about the already published cases to study the behavior of this disease entity in the GI tract, as well as in other parts of the body. Presently, the evidence suggests adequate primary surgery is essential to both local control and outcome. The other question that one may ask: why do these tumors shift to unusual sites and different tissues? The honest answer, at least at this time, would by that we do not yet know the exact mechanism for such a shift. We are involved in a larger research study to investigate the increased incidence of sarcomas in the Saudi population, particularly in the northern region, which is close to the military activities of both Gulf wars and the military activities in Iraq over the last decade.

\section{Conclusions}

In general, sarcomas are relatively rare tumor entities, particularly in the GI tract. For many reasons, it is easy to confuse the subtypes of sarcomas, including the histological similarities, the experience of the centers dealing with such tumors, proper handling, and staining and immunohistochemical findings. It is also likely to mistake such extremely rare presentations of an unusual malignancy such as synovial sarcoma for relatively more common tumors such as GISTs, which can present with more or less the same clinical scenario. The clinical importance comes from the fact that sarcomas carry a slightly worse prognosis and need a closer follow-up not to miss any sign of local recurrence or distant metastasis. We also believe that any rare presentation of any subtype of sarcoma should be carefully reported and documented to add to the relatively small pool of cases in comparison with other common malignant tumors, in order to increase our knowledge and understanding of sarcoma in general.

\section{Consent}

Written informed consent was obtained from the patient for publication of this case report and any accompanying images. A copy of the written consent is available for review by the Editor-in-Chief of this journal.

\section{Authors' contributions}

AA collected the data and informed consent, wrote the manuscript, organized the text and photos and conducted the literature review. MF reviewed the histopathological diagnosis, provided the magnified histological slide photos, followed up with other universities for confirmation of histology and histochemical diagnosis. YA provided the surgical details, followed up our patient's progress and details of her history, and reviewed the article and revised the manuscript. All authors read and approved the final manuscript. 


\section{Competing interests}

The authors declare that they have no competing interests.

Received: 2 June 2011 Accepted: 13 March 2012

Published: 13 March 2012

\section{References}

1. Billings SD, Meisner LF, Cummings OW, Tejada E: Synovial sarcoma of the upper digestive tract: a report of two cases with demonstration of the $\mathrm{X} ; 18$ translocation by flouresence in situ hybridization. Mod Pathol 2000 13:68-76.

2. Kumar V, Cotran RD, Robbins SL: Robbins Basic Pathology. 8 edition. Philadelphia, PA: Saunders; 2007.

3. Sphillane AJ, A'Hern R, Judson IR, Fisher C, Thomas JM: Synovial sarcoma: a clinicopathologica, staging, and prognostic assessment. J Clin Oncol 2000, 18:3794-3803

4. Park JK, Ham SY, Hwang JC, Jeong YK, Lee JH, Yang S, Suh J, Choi DH: Synovial sarcoma of the head and neck: a case of predominantly cystic mass. AJNR Am J Neuroradiol 2004, 25:1103-1105.

5. Pai S, Chinoy RF, Pradhan SA, D'Cruz AK, Kane SV, Yadav JN: Head and neck synovial sarcinomas. J Surg Oncol 1993, 54:82-86.

6. Zamarron C, Abdulkader I, Alvarez UC, Baron FJ, Prim JM, Ledo RL, Forteza J: Primary synovial sarcoma of the lung. Intern Med 2006, 45:679-683.

7. Etienne-Mastroianni B, Falchero L, Chalabrevesse L, Loire R, Ranchere D, Souguet PJ, Cordier JF: Primary sarcomas of the lung: a clinicopathologic study of 12 cases. Lung Cancer 2002, 38:283-289.

8. Mermigkis CM, Kopanakis A, Patentalakis G, Polychronopoulos V Patentalakis M: Primary monophasic synovial sarcoma presenting as a pulmonary mass: a case report. J Med Case Reports 2008, 2:18.

9. Nicholson AG, Rigby M, Lincoln C, Meller S, Fisher C: Synovial sarcoma of the heart. Histopathology 1997, 30:349-352.

10. Shmookler BM: Retroperitoneal synovial sarcoma. A report of four cases. Am J Clin Pathol 1982, 77:686-691.

11. Jun L, Ke S, Zhaoming W, Linjie X, Xinru Y: Primary synovial sarcoma of the prostate: report of 2 cases and literature review. Int I Surg Pathol 2008, 16:329-334.

12. Chu PG, Benhattar J, Weiss LM, Meagher-Villemure K: Intraneural synovial sarcoma: two cases. Mod Pathol 2004, 17:258-263.

13. Medina-Franco H, Ramos-De la Medina A, Cortes-Gonzalez R, Baquera J, Angeles-Angeles A, Urist MM, Eltoum IE, Heslin MJ: Expression of p53 and proliferation index as prognostic factors in gastrointestinal sarcomas. Ann Surg Oncol 2003, 10:190-195.

14. Medina-Franco H, Eltoum IE, Urist MM, Heslin MJ: Primary gastrointestinal sarcomas. Am Surg 2000, 66:1-5.

15. Miettinen M, Lasota J: Gastrointestinal stromal tumors - definition clinical, histological, immunohistochemical, and molecular genetic features and differential diagnosis. Virchows Arch 2001, 438:1-12.

16. Palmer BV, Levene A, Shaw H: Synovial sarcoma of the pharynx and oesophagus. J Laryngol Otol 1983, 97:1173-1176.

17. Amr SS, Shihabi NK, Al Hajj H: Synovial sarcoma of the esophagus. Am J Otolanyngol 1984, 5:266-269.

18. Bloch MJ, lozzo RV, Edmunds H, Brooks JJ: Polypoid synovial sarcoma of the esophagus. Gastroenterology 1987, 92:229-233.

19. Pulpeiro JR, Cruz R, Arenas A, Perez-Espejo G: Para-oesophageal synovial sarcoma. Eur J Radiol 1988, 18:120-121.

20. Caldwell CB, Bains MS, Burt M: Unusual malignant neoplasm of the esophagus. Oat cell carcinoma, melanoma, and sarcoma. J Thorac Cardiovasc Surg 1991, 101:100-107.

21. Perch SJ, Soffen EM, Whittington R, Brooks JJ: Esophageal sarcomas. J Surg Oncol 1991, 48:194-198.

22. Anton-Pacheco J, Cano I, Cuadros J, Vilarino A, Berchi F: Synovial sarcoma of the esophagus. J Pediatr Surg 1996, 31:1703-1705.

23. Habu S, Okamoto E, Toyosaka A, Takeuchi M: Synovial sarcoma of the esophagus: report of a case. Surg Today 1998, 28:401-404.

24. Bonavina L, Fociani P, Asnaghi D, Ferrero S: Synovial sarcoma of the esophagus simulating achalasia. Dis Esophagus 1998, 11:268-271.

25. Billings SD, Meisner LF, Cummings OW, Tejada E: Synovial sarcoma of the upper digestive tract: a report of two cases with demonstration of the X;18 translocation by fluorescence in situ hybridization. Mod Pathol 2000, 13:68-76.
26. Chan GS, Yuen ST, Chan KW: Synovial sarcoma presenting as a polypoid jejunal mass. Histopathology 2004, 44:191-193.

27. Butori C, Hofman V, Attias R, Mouroux J, Pedeutour F, Hofman P: Diagnosis of primary esophageal synovial sarcoma by demonstration of $t(X ; 18)$ translocation: a case report. Virchows Arch 2006, 449:262-267.

28. Akhunji S, Musil I, Baisre de Leon A, Bhattacharyya A, Cranmer LD: Synovial sarcoma arising in the gastric wall: case report and literature review. Cancer Therapy 2007, 5:457-462.

29. Parfitt JR, Xu J, Kontozoglou T, Oluwafemi AR, Driman DK: Primary monophasic synovial sarcoma of the colon. Histopathology 2007, 50:521-523.

30. Schreiber-Facklam H, Bode-Lesniewska B, Frigerio S, Flury R: Primary monophasic synovial sarcoma of the duodenum with SYT/SSX2 type of translocation. Hum Pathol 2007, 38:946-949.

31. Company-Campins MM, Morales R, Dolz C, Garcia-Bonate M, Vilella A, Huguet P: Primary monophasic synovial sarcoma of the duodenum confirmed by cytogenetic analysis with demonstration of $t(X ; 18)$ : a case report. J Gastrointestin Liver Dis 2009, 18:89-93.

32. Makhlouf HR, Ahrens W, Agarwal B, Dow N, Marshalleck JJ, Lee EL, Dotto JE, Hui $P$, Sobin $L H$, Oliveira A, Miettinen M: Synovial sarcoma of the stomach: a clinicopathologic, immunohistochemical, and molecular genetic study of 10 cases. Am J Surg Pathol 2008, 32:275-281.

33. Bergh $P$, Meis-Kindblom JM, Gherlinzoni F, Berlin O Bacchini P, Bertoni F, Gunterberg B, Kindblom LG: Synovial sarcoma: identification of low and high risk groups. Cancer 1999, 85:2596-2607.

doi:10.1186/1752-1947-6-83

Cite this article as: Alsharief et al: Monophasic synovial sarcoma presenting as a primary ileal mass: a case report and review of the literature. Journal of Medical Case Reports 2012 6:83.

\section{Submit your next manuscript to BioMed Central and take full advantage of:}

- Convenient online submission

- Thorough peer review

- No space constraints or color figure charges

- Immediate publication on acceptance

- Inclusion in PubMed, CAS, Scopus and Google Scholar

- Research which is freely available for redistribution

Submit your manuscript at www.biomedcentral.com/submit
C Biomed Central 